\title{
A QUANTITATIVE MAPPING OF ACID PHOSPHATASE IN THE BRAIN OF THE RHESUS MONKEY
}

\author{
ReinhaRd L. Friede and Mechthilde KNOller \\ Mental Health Research Institute and Department of Pathology, \\ University of Michigan, Ann Arbor, Michigan
}

(Received 31 July 1964)

THE distribution of acid phosphatase in the central nervous system as demonstrated by histochemical methods has been investigated by LANDOw, KaBAT and NEwMaN (1942), WISLOCKI and DEMPSEY (1948), and by SHIMIZU (1950) in comparative studies that included mice, rats, guinea pigs, rabbits, cats and chickens. Numerous papers deal with the cytological distribution of acid phosphatase in selected regions of the brain of various species, but little attention has been given to gradations of enzyme activity among those regions. The present paper reports a mapping of acid phosphatase activity in the brain of the rhesus monkey. A quantitative histochemical method was used, based upon spectrophotometric measurements of dye extracts from standard size tissue discs taken from brain sections that had been incubated with a substrate for acid phosphatase. Previous mappings of oxidative enzymes (FRIEDE, 1961), and particularly a mapping of lactate dehydrogenase in the brain of the rhesus monkey (FrIEDE and FLEMING, 1963), facilitate comparison of enzyme patterns.

\section{MATERIAL AND METHODS}

Histochemical method. Preliminary testing and standardization of the quantitative method for acid phosphatase activity were done on cat and monkey brains; a detailed account of methodology will be given elsewhere. For the present experiment three adult, healthy rhesus monkeys were killed under pentothal anaesthesia; the brains were removed immediately and placed in $10 \%$ formalin at $4^{\circ}$. After $8 \mathrm{hr}$ fixation, the material was cut into slices, 3-5 mm thick. Twenty-four hours after removal of each brain, $30 \mu$ frozen sections were cut, rinsed, and stored in chilled distilled water until all material from the brain had been prepared. All sections were transferred to a 4-litre Erlenmeyer flask containing a small portion of the buffer component of the incubation medium. The substrate and diazo salt were mixed with the remaining portion of the buffer and filtered as quickly as possible; the filtrate was added immediately to the sections and buffer in the Erlenmeyer flask and incubation was started.

The incubation medium was a mixture of $1 \mathrm{mg}$ of sodium- $\alpha$-naphthyl phosphate (Sigma Chemical Co. St Louis, Missouri) and $1 \mathrm{mg}$ of the stable diazotate of $o$-amino azotoluene (Fast Garnet GBC) (Dajac Laboratories, Philadelphia) in $1 \mathrm{ml}$ of 0.2 M-Walpole buffer of pH 5 (Pearse, 1960). For each monkey brain approximately $2 \mathrm{l}$. of reaction mixture were used. The sections were incubated in an Eherbach water-bath shaker with constant agitation for $1 \mathrm{hr}$ at $38^{\circ}$. The reaction was stopped by transferring all sections into a large quantity of $10 \%$ formalin.

The stained sections were mounted temporarily on a microslide covered with three layers of parafilm. Discs were cut from selected areas of the sections with stainless steel tubes, $1.1 \mathrm{~mm}$ and $2.4 \mathrm{~mm}$ in diameter. Each disc was placed in a stoppered test tube containing a drop of distilled water. Care was taken not to transfer particles of parafilm into the tubes since these would cause turbidity and false readings. The azo dye was extracted with $1 \mathrm{ml}$ of chloroform-ethanol (1:1), v/v and the colour density was determined within $10-30 \mathrm{~min}$ at $555 \mathrm{~m} \mu$ in microcells in a Beckman DU spectrophotometer. For the data collected in Table I an average of ten samples were taken from the regions indicated for each monkey, and means and standard deviations were calculated.

The dependability of this method was tested in various experiments (unpublished data) the results of which are only briefly summarized: tissue fixed in formalin after incubation was used since it was impractical to cut discs from loose sections. During the required 24-hr fixation period, some loss of 
enzyme activity occurred; however, no further decrease of activity was observed when fixed sections were stored in chilled distilled water up to 5 days. These procedures had no noticeable effect on the regional gradations of enzyme activity. When tissue sections from the same specimen were incubated for $30,45,60$ or $90 \mathrm{~min}$ and discs were cut from white matter, cortex and caudate nucleus, a straightline relation between incubation time and intensity of staining was obtained up to $60 \mathrm{~min}$ for all three areas. If sections of different thickness were incubated, the staining intensity in any given test region increased proportionally to thickness up to $45 \mu$, but not in thicker sections. There was no nonspecific absorption of dye, even when free dye was produced in the medium; on the contrary, when $1 \mathrm{mg}$ or more of commercial acid phosphatase was added per $\mathrm{ml}$ of medium, the resulting enzyme reaction in the medium was competitive with the dye formation of the tissue.

If the volume of tissue per volume of medium was increased, the overall staining intensity of the individual section decreased, but the ratios of staining intensities among nuclei remained unchanged. Since the ratio of volume of tissue to volume of medium can only be estimated with series of hundreds of sections of different size, a slight variation in the overall staining intensity usually occurs with different experiments. However, for measuring ratios of enzyme activity among regions of a given sample, the method gave reproducible results (Table 1) that compared precisely with those obtained by biochemical assays (Fig. 1). To facilitate direct comparison among samples of different overall staining intensity, a correction factor was used in Table 1. The use of this factor also emphasizes that histochemical data should be interpreted only within their limited range of reliability, that is, for the demonstration of patterns and ratios within a given sample.

Table 1.-Histochemical measurements of ACID phosphatase in the NUCLEI AND REGIONS OF MONKEY BRAIN

Region $\begin{array}{ccccc}\begin{array}{c}\text { Type of } \\ \text { region } \\ \text { (see text) }\end{array} \text { I } & \text { Monkey } & \text { II } & \text { III } & \text { Average sampling problems }\end{array}$

\section{MEDULLA} OBLONGATA

N. tractus desc. nerv. trigemini

N. tractus solitarii

N. reticularis

N. vestibularis lat.

Tractus pyramidalis

\section{CEREBELLUM}

Cortex

\section{$\mathrm{N}$, fastigii \\ N. dentatus \\ Substantia alba \\ PONS}

N. reticularis

$N$. nerv, abducentis

N. vestibulari s sup.

N. pontis

(compact pts.)

Tractus pyramidalis Brachia pontis

\section{-
B
B
A}

-

$$
81 \pm 4
$$

$64 \pm 9$

$88 \pm 7$

$28 \perp 6$

$127 \pm 4$

10

102
$88 \div 6$

76

$104 \div 10$

$58 \pm 4$

$95 \div 3$

$60 \div 3$

$81+1170 \pm 3$

$18+429+3$

$87 \pm 6$

$\begin{array}{llll}\text { C } & & 38 \pm 4 \\ \text { C } & 92 \pm 7 & 64 & 6 \\ \text { A } & 32 \pm 3 & 24 \pm 4 & 21 \pm 3\end{array}$

C.

B

B

C

$\begin{array}{ccc} & 83 \pm 7 & 58 \pm 5 \\ 95 \pm 5 & 72 \pm 6 & - \\ 68 \pm 11 & 72 \pm 7 & 62 \pm 8 \\ 42 \pm 3 & 28 \pm 2 & 27 \pm 5 \\ 24 \pm 7 & 34 \pm 4 & -\end{array}$

101

Smail nucleus

61

80

25

No explanation

Samples I and II including a larger portion of granular layer.

Regional variation
$84 \quad$ Small nucleus

84 Irregular structure

67 Transfixing fibre bundles

No explanation

Measurements are expressed in optical densities: $10^{-3}$ of azo dye formed per $0.131 \mathrm{~mm}^{\mathrm{s}}$ formalinfixed tissue per hour at $38^{\circ}$. The experiments varied in overall staining intensity; to facilitate comparison of measurements, correction factors of 1.6 for monkey II and 0.71 for monkey III were used. Each datum represents the mean and standard deviation of measurements from ten different samples; only for a few of the smaller nuclei were less than ten samples obtained. 
TABLE 1 (Con't $d$ )

\begin{tabular}{|c|c|c|c|c|c|c|}
\hline Region & $\begin{array}{l}\text { Type of } \\
\text { region } \\
\text { (see text) }\end{array}$ & I & $\begin{array}{c}\text { Monkey } \\
\text { II }\end{array}$ & III & Average & $\begin{array}{l}\text { Remarks concerning } \\
\text { sampling problems* }\end{array}$ \\
\hline $\begin{array}{l}\text { MIDBRAIN } \\
\text { (colliculus inferior) }\end{array}$ & & & . & & & \\
\hline $\begin{array}{l}\text { Colliculus inferior } \\
\text { Griseum centrale }\end{array}$ & B & $74 \pm 9$ & $84 \pm 5$ & $80 \pm 6$ & 79 & - \\
\hline (dorsal portion) & B & $88 \pm 12$ & $91 \pm 8$ & $95 \pm 7$ & 91 & - \\
\hline N. medianus raphes & $\mathrm{C}$ & $76 \pm 8$ & $78: 6$ & & 77 & - \\
\hline N. reticularis & C & $69 \pm 2$ & $66 \pm 5$ & $65 \pm 7$ & 67 & - \\
\hline \multicolumn{7}{|l|}{$\begin{array}{l}\text { MIDBRAIN } \\
\text { (colliculus superior) }\end{array}$} \\
\hline \multicolumn{7}{|l|}{$\begin{array}{l}\text { Colliculus superior } \\
\text { (lamina super- }\end{array}$} \\
\hline $\begin{array}{l}\text { Colliculus superior } \\
\text { (laminae profundae) }\end{array}$ & B & $62=6$ & $66 \pm 7$ & $60+7$ & 63 & -.. \\
\hline Griseum centrale & $\mathrm{C}$ & $95 \pm 7$ & $95+8$ & $95 \pm 11$ & 95 & - \\
\hline $\begin{array}{l}\text { N. nerv. } \\
\text { oculomotorii }\end{array}$ & - & $97 \pm 7$ & $96 \pm 9$ & $60 \pm 2$ & & Small nucleus \\
\hline N. niger & B & $87 \pm 11$ & $82 \pm 8$ & $89 \pm 10$ & 86 & - \\
\hline Pedunculi cerebri & A & $40 \pm 9$ & $43 \pm 5$ & $30 \pm 3$ & 38 & 一 \\
\hline N. reticularis & $\mathrm{C}$ & $63+5$ & 65 t: 6 & $56 \pm 5$ & 61 & -- \\
\hline \multicolumn{7}{|l|}{ DIENCEPHALON } \\
\hline $\begin{array}{l}\text { N. latcralis thalami } \\
\text { Region of } N \text {. }\end{array}$ & B & $79 \pm 8$ & $72 \dashv 4$ & $77+4$ & 76 & - \\
\hline $\begin{array}{l}\text { dorsomedialis } \\
\text { N. geniculatus }\end{array}$ & B & $79 \pm 7$ & $79 \pm 6$ & $87 \pm 5$ & 82 & - \\
\hline lateralis & - & & $79 \div 7$ & $64 \pm 4$ & 72 & $\begin{array}{l}\text { Interspaced laminae } \\
\text { of white matter }\end{array}$ \\
\hline Capsula interna & A & $36 \pm 2$ & $29 \pm 6$ & $27 \pm 2$ & 31 & 一 \\
\hline Tractus opticus & A & $26 \pm 4$ & $37 \pm 2$ & $27 \pm 4$ & 30 & - \\
\hline Tuber cinereum & B & $83 \pm 8$ & $91 \pm 9$ & $92 \pm 11$ & 89 & - \\
\hline N. subthalamicus & - & $109 \pm 10$ & - & $88 \pm 8$ & 98 & Irregular shape \\
\hline \multicolumn{7}{|l|}{$\begin{array}{l}\text { BASAL TELENCE- } \\
\text { PHALIC CENTRES }\end{array}$} \\
\hline N. caudatus (caput) & B & $78+7$ & $108 \pm 6$ & $90 \pm 12$ & 92 & $\begin{array}{c}\text { True regional } \\
\text { variations }\end{array}$ \\
\hline $\begin{array}{l}\text { Putamen (anterior } \\
\text { portion) }\end{array}$ & B & $76 \pm 7$ & $102+8$ & $89 \pm 7$ & 89 & - \\
\hline $\begin{array}{l}\text { Putamen (posterior } \\
\text { portion) }\end{array}$ & B & $73 \pm 7$ & $73 \pm 6$ & $89+6$ & 78 & - \\
\hline Pallidum externum & $\mathrm{C}$ & $61+7$ & $70 \pm 7$ & $76 \pm 6$ & 69 & - \\
\hline Pallidum internum & C & $67 \pm 5$ & $86 \pm 7$ & $75 \pm 7$ & 76 & - \\
\hline Capsula interna & A & $38 \pm 3$ & $42+4$ & $41 \pm 6$ & 40 & $\begin{array}{l}\text { Taken close to } \\
\text { gray matter }\end{array}$ \\
\hline N. amygdalae & B & $79 \pm 6$ & & & & \\
\hline \multicolumn{7}{|l|}{$\begin{array}{l}\text { FRONTAL } \\
\text { CORTEX }\end{array}$} \\
\hline Cortex & B & $76 \pm 6$ & $98 \pm 12$ & $98 \pm 11$ & 91 & $\begin{array}{l}\text { Proportion of layers } \\
\text { varied in samples }\end{array}$ \\
\hline $\begin{array}{l}\text { Substantia alba } \\
\text { PARIETAL CORTEX }\end{array}$ & \multicolumn{5}{|c|}{ PARIETAL CORTEX } & No explanation \\
\hline Cortex & B & $83 \pm 6$ & $89 \pm 10$ & $106 \pm 7$ & 93 & $\begin{array}{l}\text { Proportion of layers } \\
\text { varied in samples }\end{array}$ \\
\hline Substantia alba & A & $39 \neq 5$ & $27 \pm 5$ & $29 \pm 4$ & 32 & - \\
\hline
\end{tabular}


TABLE 1 ( Cont'd)

\begin{tabular}{|c|c|c|c|c|c|c|}
\hline Region & $\begin{array}{l}\text { Type of } \\
\text { region } \\
\text { (see text) }\end{array}$ & $\mathrm{I}$ & $\begin{array}{l}\text { Monkey } \\
\text { II }\end{array}$ & III & Average & $\begin{array}{l}\text { Remarks concerning } \\
\text { sampling problems }\end{array}$ \\
\hline \multicolumn{7}{|l|}{ OCCIPITAL CORTEX } \\
\hline Cortex (Area 18) & B & $78 \pm 4$ & $93 \pm 4$ & $110 \pm 8$ & 94 & $\begin{array}{l}\text { Proportion of layers } \\
\text { varied in samples }\end{array}$ \\
\hline Cortex (Area 17) & B & $72+4$ & $84 \div 11$ & $93 \pm 7$ & 83 & \\
\hline Substantia alba & A & $43+3$ & $59+6$ & 35.13 & 46 & $\begin{array}{l}\text { Sample II adjacent } \\
\text { to cortex }\end{array}$ \\
\hline \multicolumn{7}{|l|}{$\begin{array}{l}\text { TEMPORAL } \\
\text { CORTEX }\end{array}$} \\
\hline $\begin{array}{l}\text { Cortex } \\
\text { Substantia alba }\end{array}$ & $\frac{\mathrm{B}}{-}$ & $\begin{aligned} 103 & \pm 9 \\
41 & \pm 13\end{aligned}$ & $110 \pm 5$ & $133 \pm 14$ & 115 & $\begin{array}{l}\text { Sampled immedi- } \\
\text { ately subcortical }\end{array}$ \\
\hline \multicolumn{7}{|l|}{$\begin{array}{l}\text { DEEP TEMPEROL } \\
\text { CORTEX }\end{array}$} \\
\hline Cortex subiculum & - & $85 \pm 3$ & $106 \pm 13$ & $106 \pm 8$ & & $\begin{array}{l}\text { Proportion of layers } \\
\text { varied among } \\
\text { samples }\end{array}$ \\
\hline Substantia alba & - & $43 \pm 7$ & $45 \pm 7$ & $43 \pm 4$ & 44 & $\begin{array}{l}\text { Sampled immedi- } \\
\text { ately subcortical }\end{array}$ \\
\hline $\begin{array}{l}\text { Ammon's horn (total) } \\
\text { (Selective samplings of } \\
\text { pyramidal layer of } \\
\text { fasc. dent. and }\end{array}$ & 一 & 92 t. 8 & $92 \div 8$ & 112 t1 11 & & - \\
\hline $\begin{array}{l}\text { Ammon's horn) } \\
\text { Ammon's horn } \\
\text { (selective sampling }\end{array}$ & - & $101 \pm 16$ & $120 \pm 9$ & $130 \pm 6$ & 117 & - \\
\hline of molecular layer) & - & $87 \pm 13$ & $95 \pm 3$ & $51 \pm 2$ & & - \\
\hline \multicolumn{7}{|l|}{ AVERAGES } \\
\hline $\begin{array}{l}\text { (A) Average for pure } \\
\text { (B) Average for pure } \\
\text { (C) Average for samp } \\
\text { include transfixing } \mathrm{f}\end{array}$ & $\begin{array}{l}\text { samples o } \\
\text { ples of gra } \\
\text { fibre bund }\end{array}$ & $\begin{array}{l}\text { f white ma } \\
\text { f gray matt } \\
\text { y matter th } \\
\text { lles: } 67\end{array}$ & $\begin{array}{l}\text { tter: } 33 \\
\text { ter: } 87 \\
\text { at invariat }\end{array}$ & & & \\
\hline
\end{tabular}

* Homogeneous samples were difficult to obtain in very small, irregularly-shaped nuclei or in nuclei with transfixing fibre bundles because of varying occurrence of fibre bundles or of contamination with adjacent tissue. Wherever such sampling difficulty occurred, an explanatory note has been added in the Table. In the cerebral and cerebellar cortex, and in the Ammon's horn, discs were taken both from sections cut perpendicular to the cortical surface (which included variable proportions of the individual layers) and from slanted sections that contained pure samplings of layers. However, a detailed sampling of the cortical layers was beyond the scope of this study, and the present data refer only to gross averages. The neuropil of the caudate nucleus showed considerable regional variation of acid phosphatase, which was not related to transfixing fibre bundles. Subcortical samples of white matter were not included in group $\mathbf{A}$.

Biochemical method. Homogenates were prepared from seven regions of the brains of three rhesus monkeys. Gomori's (1949) phenol method for phosphatases was adapted and standardized for tissue homogenates. The substrate mixture consisted of $90 \mathrm{ml}$ of $0.5 \mathrm{M}$-acetate buffer at $\mathrm{pH} 5$ and $10 \mathrm{ml}$ of approximately $0.05 \mathrm{M}$-disodium-phenylphosphate; $0.1 \mathrm{ml}$ of whole homogenate was added to $3 \mathrm{ml}$ of freshly prepared, buffered substrate in $25 \mathrm{ml}$ volumetric flasks. Triplicate determinations were carried out for each unknown; duplicate blanks, containing buffered substrate only, were run with each sample. Unknowns and blanks were incubated for $1 \mathrm{hr}$ in a constant-temperature water-bath shaker at $38^{\circ}$, and transferred to chilled test tubes; $0.1 \mathrm{ml}$ of homogenate was added to each blank. Without delay all samples were centrifuged for $3 \mathrm{~min}$, and $1 \mathrm{ml}$ portions of the supernatant were pipetted into $9 \mathrm{ml}$ of borax solution ( $4 \mathrm{ml}$ of $15 \%$ ethanol saturated with borax and $5 \mathrm{ml}$ of distilled water). Components were mixed with a Vortex Jr. mixer, $0.5 \mathrm{ml}$ of diazo reagent was added, and the solutions were immediately mixed again. Colour development took place within 10 min. Samples 
were measured between 10 and $60 \mathrm{~min}$ in a Beckman DU spectrophotometer; optimal wavelength was $410 \mathrm{~m} \mu$. A standard curve was prepared from dilutions of a stock solution of phenol; the phosphatase activity was expressed as $\mu \mathrm{g}$ of phenol liberated per mg wet tissue per hour at $38^{\circ}$.

\section{RESULTS}

Material from three rhesus monkeys was used to obtain histochemical measurements of acid phosphatase activity in fifty four regions of the brain (Table 1). Measurements from caudate nucleus, putamen, lateral thalamic nucleus, temporal cortex, parietal cortex, optic tract, and parietal white matter were compared with

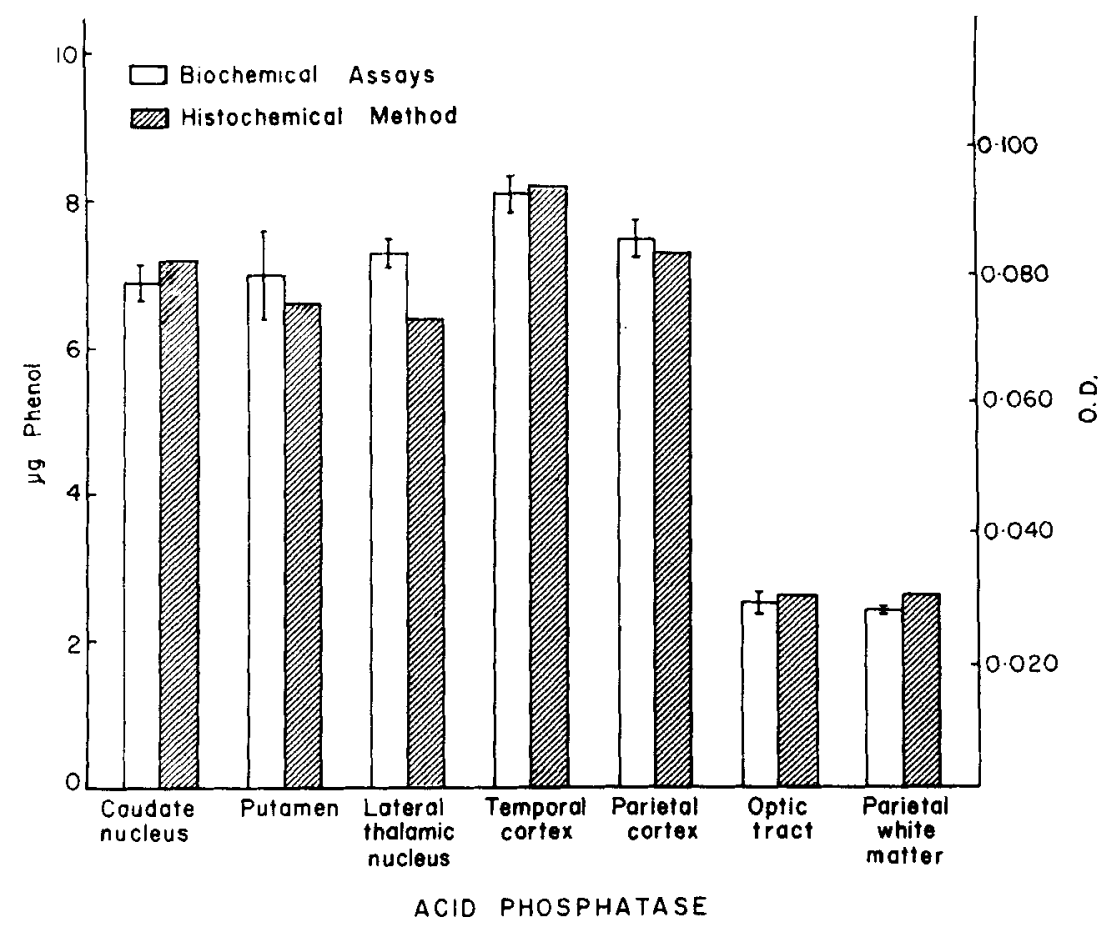

FIG. 1.-Comparison of biochemical assay data with histochemical measurements of acid phosphatase activity in the rhesus monkey brain. Biochemical data are expressed as $\mu \mathrm{g}$ of phenol liberated per $\mathrm{mg}$ wet tissue per hour at $38^{\circ}$; triplicate determinations were performed for each region in three animals. Histochemical measurements are given in optical densities of azo dye formed per $0.131 \mathrm{~mm}^{3}$ per hour at $38^{\circ}$. Ten determinations were made in each region in three animals.

biochemical assay data obtained from the same regions; results showed good agreement (Fig. 1). Histochemical measurements were also compared with microscopic observations (Figs. 2-6) from the same series of sections; both approaches showed: (1) a gradient of acid phosphatase activity between gray and white matter; (2) quantitative similarity, but cytological variation, of enzymic activity in different areas of gray matter; and (3) exceptionally high enzymic activity in a few nuclei and non-neuronal structures.

(1) Distribution pattern of acid phosphatase activity in gray and white matter. Gray matter showed more acid phosphatase activity than did white matter. Pure samples from white matter are labelled $\mathrm{A}$ in Table 1; samples of gray matter from regions 
where pure samples were easily obtained are labelled B. The averages for the histochemical measurements (Table 1 , bottom) in groups A and B indicate a ratio of white matter to gray matter of $1 \cdot 0: 2.9$; the biochemical measurements gave a ratio of $1 \cdot 0: 3 \cdot 0$. Samples of gray matter from regions where transfixing fibre bundles are invariably present are labelled $\mathrm{C}$. The ratio of white matter in group $\mathrm{A}$ to gray matter in group $\mathrm{C}$ consequently was only $1 \cdot 0: 2 \cdot 2$. ALBERT (1955) obtained a ratio of human white matter to cortex of $1 \cdot 0: 2 \cdot 3$. SAMORAJSKI and FITZ (1961) found a ratio of roughly $1 \cdot 0: 2 \cdot 0$ of anterior spinal tracts to anterior gray columns. In the Ammon's horn, the gradient between the white layer of the alveus and the various gray layers ranged between $1 \cdot 0: 1.9$ and $1 \cdot 0: 2 \cdot 7$ (on the basis of protein; LoWRY, ROBERTs, LeINER, Wu, Farr and Albers, 1954). Robins, Smith and Eydt (1956) reported a substantially higher gradient for monkey white matter:cerebral cortex (dry weight); their ratio of cerebellar white matter to cortex was similar to the above data if based on protein $(1 \cdot 0: 2 \cdot 8-3 \cdot 1)$, but higher if based on dry weight (RoBins and SMITH, 1953).

The white matter of the cerebral hemispheres showed a gradual increase of acid phosphatase activity from the central portion toward the cortex, with markedly more acid phosphatase activity in the subcortical zone (Fig. 6). The latter was not caused by diffusion of the dye; the borderline between gray and white matter was usually distinct in the medulla oblongata where fibre tracts traversed or passed at the periphery of nuclei, or in other tracts, e.g. the anterior commissure (Fig. 5). Testing for lipid solubility of the dye also gave negative results (unpublished). Variation in measurements from hemispheric white matter could always be correlated to variation of sampling within that area (see Remarks in Table 1).

Microscopically, the staining of white matter appeared diffuse; glia cells were not discernible. Glial staining was probably not visualized because of the thickness of the sections and mounting in glycerin-gel; other authors (ANDERSON and SONG, 1962) demonstrated acid phosphatase in gliacells. Staining of axons could be observed only in some tracts that presented very thick axons; for example, the roots of cranial motor nerves, the pyramidal tract, frontal portions of corpus callosum, and fibres of the corpus trapezoides.

(2) Similarity of the levels of acid phosphatase activity in different regions of gray matter. Histochemical measurements of acid phosphatase activity of twenty-two regions of gray matter showed surprisingly little variation. The average values were $87 \pm 7$ (S.D.) (Table 1, bottom). Even measurements for such regions as the motor nuclei of the medulla, thalamic nuclei, basal ganglia, hypothalamus, central gray matter, and cerebral cortex were within a close range. Microscopically, there was rather homogeneous staining of nuclei (Figs. 2-4) and gradations seemed to depend largely on the amount of transfixing fibres.

An effort was made to correlate measurements with the microscopic distribution of enzyme activity in various nuclei. Three types of cytochemical distribution patterns were observed: (a) Parvicellular nuclei showed diffuse distribution of acid phosphatase throughout the neuropil, and no nerve cells were discernible. This pattern was characteristic for most sensory nuclei of the medulla oblongata (Figs. 2, 3), the griseum centrale of the 4th ventricle and the aqueduct (Fig. 4), parts of the colliculus inferior, most parts of the tuber cinereum (Fig. 5), the medial thalamic nuclei, and the superficial layers of cerebral cortex. (b) Magnicellular nuclei showed a preponderance of enzymeactivity in the nerve cells and little, or variable, staining in the neuropil. Such nuclei 


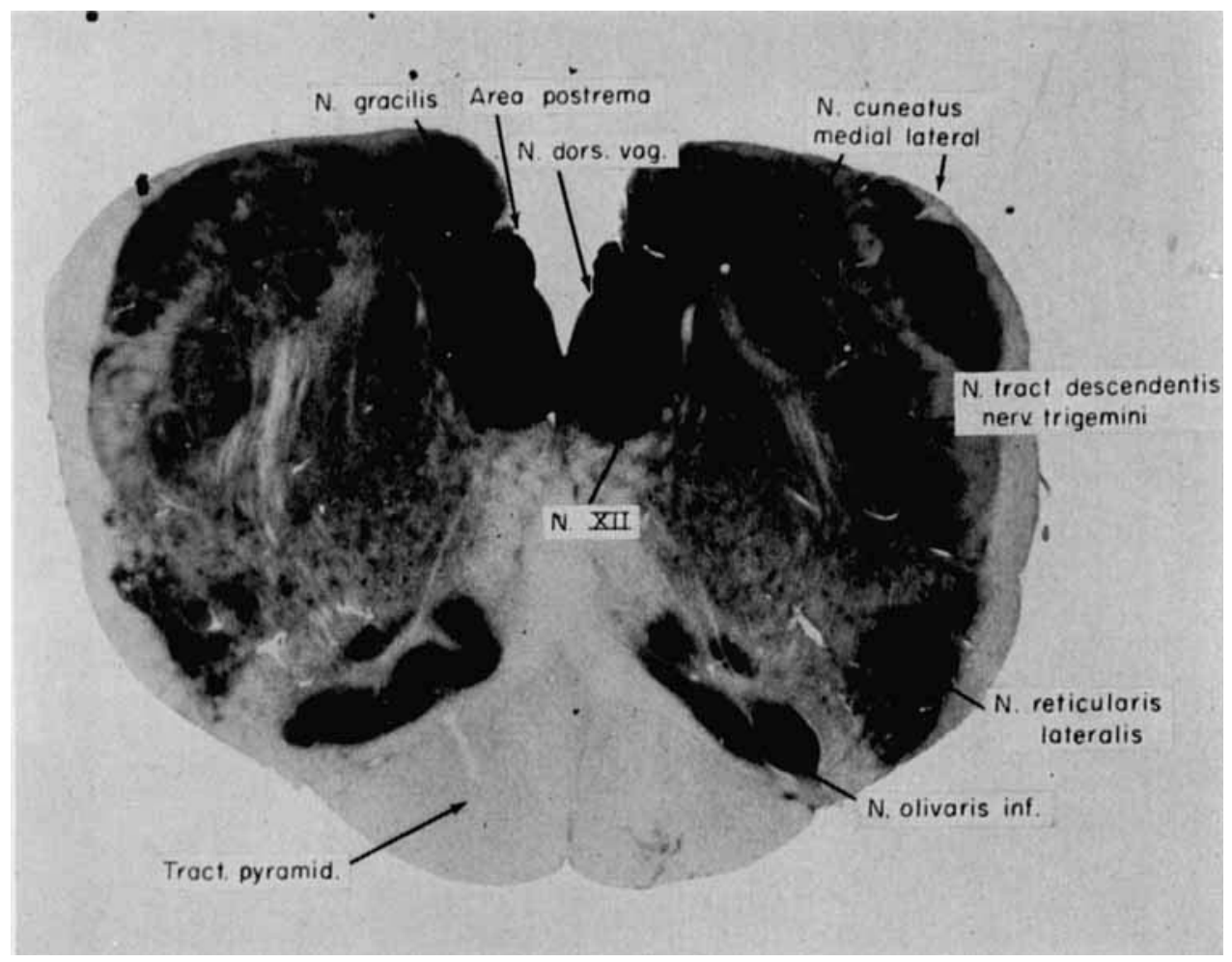

FIG. 2.--Survey of acid phosphatase in a transverse section of the lower medulla oblongata at the level of the hypoglossal nucleus; the most intense reaction is found in the area postrema. The cells of the dorsal vagal nucleus also give very intense staining, approximately equal to that given by the cells of the hypoglossal nuclei. $16 \times$. 


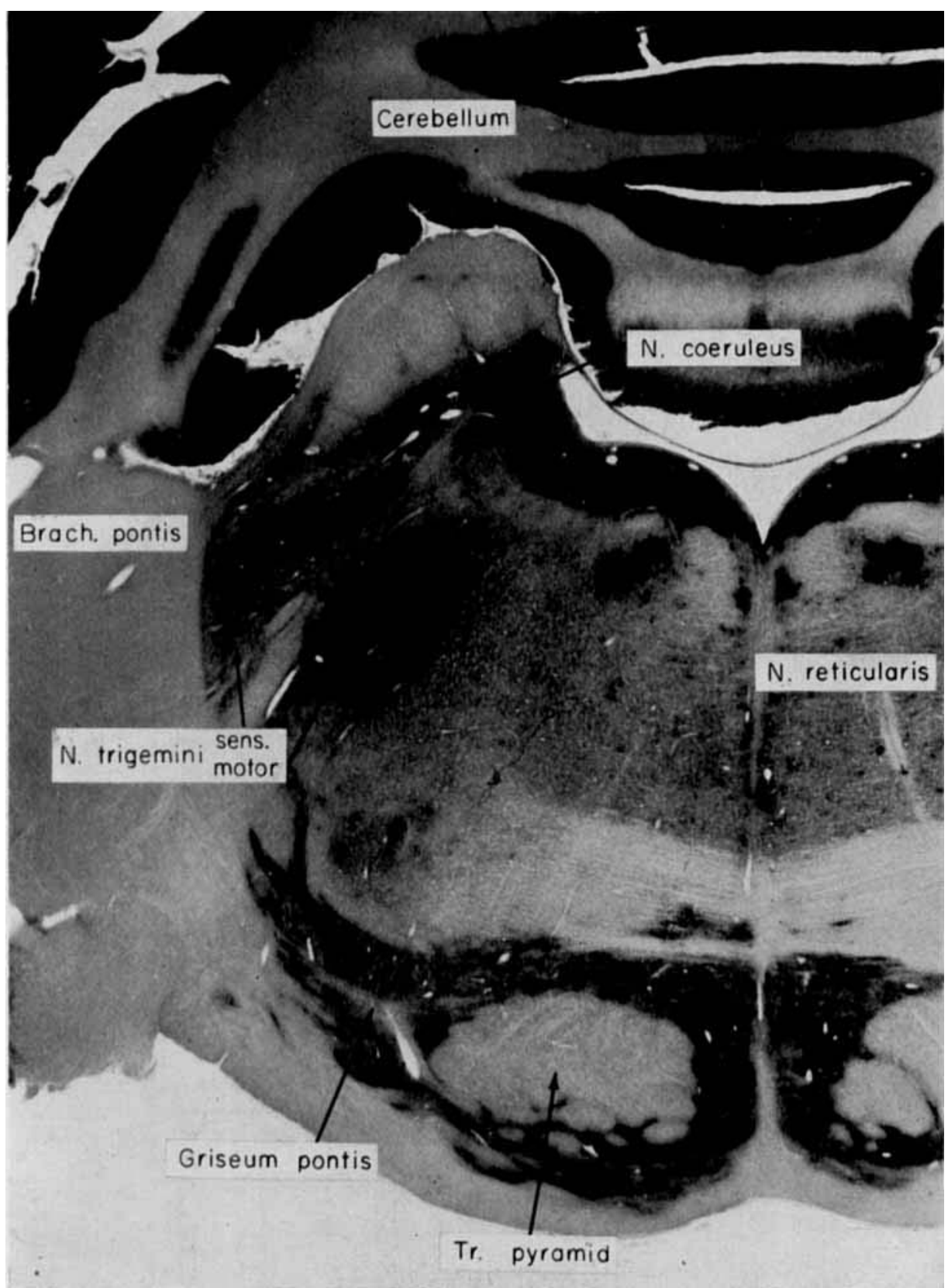

FIG. 3.- Survey of acid phosphatase in a transverse section at the most caudal level of the pons. Gradations of acid phosphatase among nuclei are slight except for a marked reaction in the cerebellar cortex where activity is particularly high in the Purkinje cells. The $N$. coeruleus and cell groups near the fasciculus longitudinalis medialis exhibit exceptionally strong staining. $15 x$. 


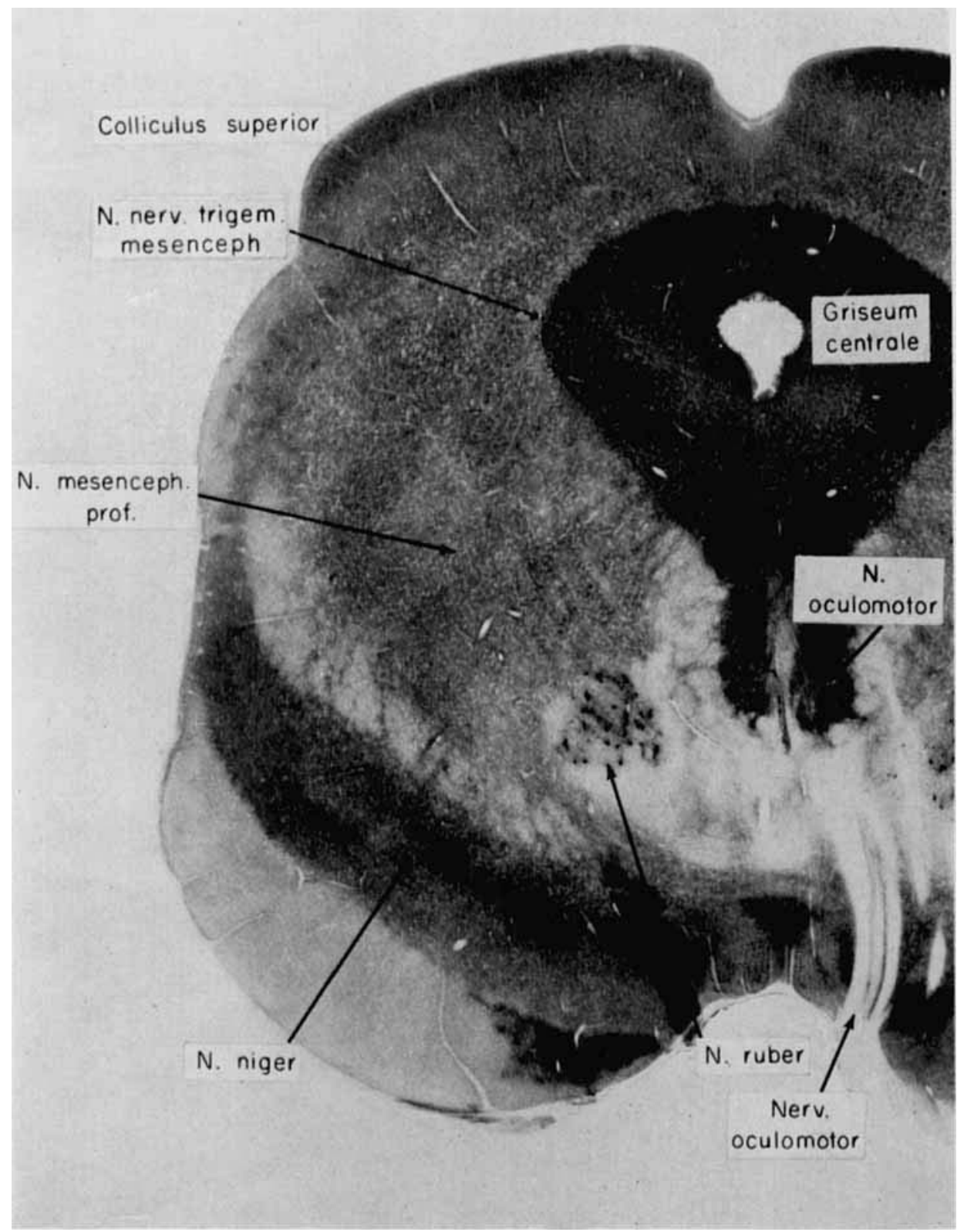

FIG. 4.-Transverse section of the midbrain at the level of the colliculi superior. High levels of activity are seen in the perikarya of the red nucleus and the nucleus of the mesencephalic trigeminal root. Under higher power, a marked reaction is also seen in the cells of the oculomotor nucleus and substantia nigra. $12 \times$. 


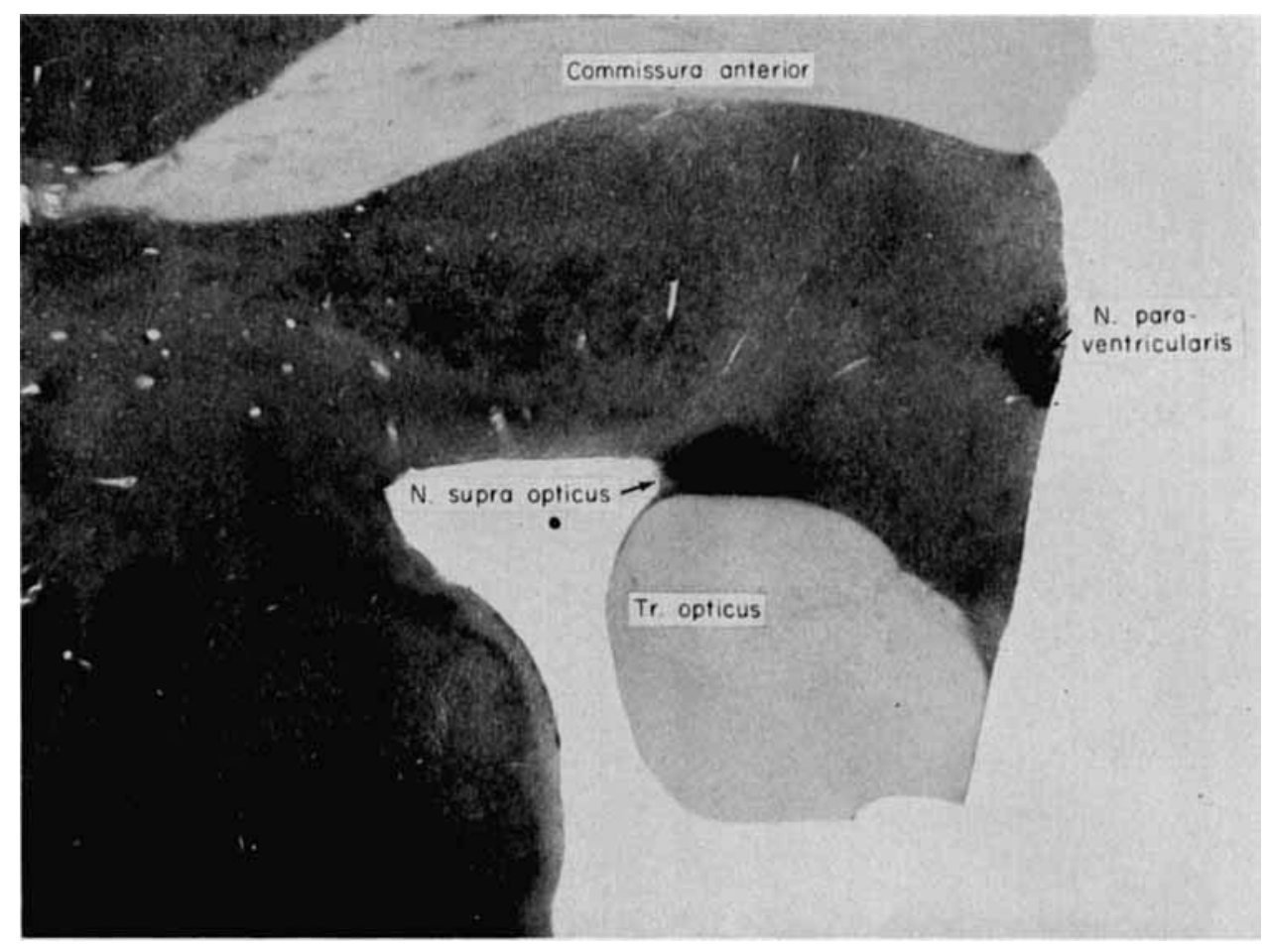

FIG. 5.-Section of hypothalamus in a frontal plane including optic tract and anterior commissure; portions of the temporal lobe are seen in the left lower corner. The straight surface at the right is the wall of the third ventricle. Exceptionally intense staining is present in the supraoptic and paraventricular nuclei. $16 \times$. 


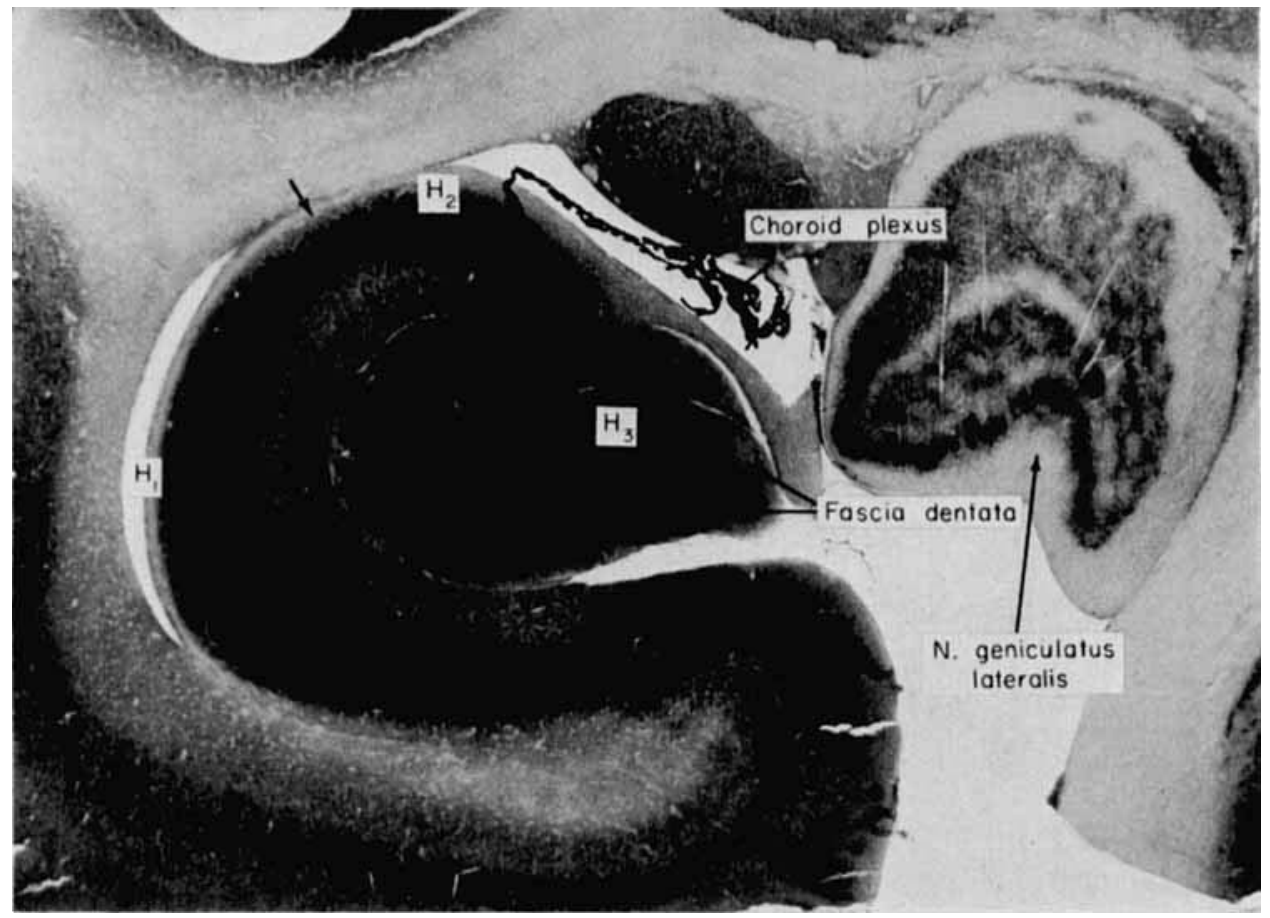

FIG. 6.-Ammon's horn, showing the exceptionally intense staining in the sector $\mathrm{H} 2$ and in the cells of the fascia dentata. The intense staining of the choroid plexus is not continuous with the ependyma. Note also the comparatively weak staining of the $\mathbf{N}$. geniculatus lateralis and the subcortical increase of acid phosphatase in the temporal white matter. $16 \times$. 
included all cranial nerve motor nuclei, the N. cuneatus lateralis (Figs. 2, 3), N. vestibularis, $N$. cochlearis, N. trapezoides, $N$. olivaris superior, N. reticularis, the cerebellar nuclei, the nucleus of the mesencephalic trigeminal root, N. ruber (Fig. 4), N. pallidus, and the $\mathrm{N}$. reticularis thalami. Cells with maximal staining included Purkinje cells (Fig. 3), Betz motor cells, mesencephalic trigeminal cells (Fig. 4), Deiter's cells, and the cells of the red nucleus (Fig. 4). The correlation of cell size and acid phosphatase activity has been emphasized by numerous authors including LANDOw et al. (1942), Shimizu (1950), and ANDERSon and Song (1962). (c) Nuclei with mixed cell populations showed diffuse distribution of intense staining throughout the neuropil; only the large cells, which stained markedly stronger than the neuropil, were discernible. Such regions included the N. vestibularis medialis, N. caudatus and putamen (few cells), the amygdala (which contained a few prominently stained cells), the lateral thalamic nuclei (numerous cells), and the deep cortical layers (particularly in the cingular cortex where many cells were seen). The $\mathrm{N}$. olivaris inferior, $\mathrm{N}$. geniculatus lateralis, and the griseum pontis showed marked staining both in their nerve cells and in the neuropil.

Since cytological patterns of acid phosphatase activity differed more among nuclei than did the overall measurements of enzyme activity, a reciprocal relationship between enzyme activities in perikarya and in neuropil was assumed. For example, only a small quantitative difference was found between putamen (78) and pallidum (69) (Table 1); yet, nearly all enzymic activity in the putamen was in the neuropil (except for the scattered large neurons) while nearly all enzymic activity in the pallidum was in its large nerve cells. Similarly, a small quantitative difference in acid phosphatase activity was observed between the $N$. niger (86), where staining was seen in neuropil and nerve cells, and the griseum centrale (95), where all staining was diffusely distributed throughout the neuropil.

(3) Exceptionally high acid phosphatase activity in certain nuclei and non-neuronal structures. A few nuclei showed an unusually high staining intensity due to disproportionately high enzyme activity in the cells; these were clearly visible as dark spots to the naked eye (Fig. 5). For the nuclei supraopticus and paraventricularis (Fig. 5) these findings are in agreement with numerous previous reports (ERÄNKÖ, 1951; Naidoo and Pratt, 1951; LeduC and Wislocki, 1952; Scharrer and SCharrer, 1954; Cohn and Richter, 1956; Kivalo, Rinne, and Mäkelä, 1958; SAmorajski and FITZ, 1960). Since these nuclei were too small to permit measurements with the method described above, the staining intensities were estimated with a Densichron densitometer from sections projected on a photographic screen. The following ratios were recorded: optic nerve, 1.0 ; commissura anterior, $1 \cdot 1$; substantia alba, parietal, 1.2 ; hypothalamus, 2.4 ; putamen, 2.8 ; paraventricular nucleus, 3.0 ; supraoptic nucleus $4 \cdot 8$. These measurements substantiate the markedly stronger staining in these nuclei as seen in Fig. 5.

Intense staining was also found in the $\mathrm{H} 2$ segment of the pyramidal layer of the Ammon's horn and in the cell layer of the fascia dentata. There was a sharp contrast between the portions $\mathrm{H} 2$ and $\mathrm{H} 1$ and also between $\mathrm{H} 2$ and $\mathrm{H} 3 ; \mathrm{H} 1$ had only slightly more activity than the subiculum (Fig. 6). This staining pattern was observed by FLEISCHHAUER (1959) who, however, erroneously called the intensely staining segment H3. Unfortunately, these patterns cannot be compared with the measurements by LOWRY and coworkers (1954) since the specific segment of Ammon's horn was not 
identified for these measurements. An effort was made to obtain samples of the most darkly staining portions of the pyramidal layer and of molecular layer in tangential sections (Table 1); the gradient between these layers was evident, but contamination from adjacent tissues caused varying measurements.

The intensity of staining in cells of the $N$. coeruleus, in medial cell groups near the fasciculus longitudinalis (Fig. 3), the N. supratrochlearis, and N. dorsalis vagi (Fig. 2) was in striking contrast to the diffuse reaction observed throughout the neuropil of the adjacent griseum centrale. Similarly high in acid phosphatase activity were a small cell group at the ventral surface of the pallidum (probably identical with the nucleus ectopeduncularis), scattered cells in the lateral tuber cinereum (Fig. 5), and the septal area near the commissura anterior. The area postrema showed intense staining throughout its parenchyma (Fig. 2) (CAMMERMEYER, 1949).

Among the non-neuronal structures, the choroid plexus showed very high enzyme activity, occasionally exceeding that of the most intensely stained nerve cells of the brain. The enzyme activity in the plexus epithelium was higher than in the ependyma, and a sharp contrast in staining was seen at the junction (Fig. 6). A few scattered histiocytes in the spaces of Virchow-Robin also showed intense staining, while little activity was seen in meninges or in the walls of blood vessels.

Comparison of acid phosphatase distribution with oxidative enzyme patterns. Comparisons were made between the present measurements of acid phosphatase activity and previous measurements of lactate dehydrogenase activity in the rhesus monkey (FRIEDE and FLEMING, 1963). Measurements for both enzymes were available for thirty seven regions of the brain; for these regions a correlation coefficient of 0.76 was calculated. In contrast, measurements of various oxidative enzymes and of capillarization in the medulla oblongata usually gave correlation coefficients above 0.85 even among different species (FRIEDE, Fleming and KNOLLER, 1963). The present correlation coefficient reflects mainly the gradation between gray and white matter, which is similar for both enzymes. If only measurements of gray matter were compared, a correlation coefficient of 0.28 was obtained; this result indicated marked dissimilarities in gradations of acid phosphatase and lactate dehydrogenase among nuclei.

Most nuclei of exceptionally high acid phosphatase activity also showed exceptionally strong activities of lactate dehydrogenase and glucose 6-phosphate dehydrogenase but very little activity of the citric acid cycle enzymes (FRIEDE, FLEMING and KNOLLER, 1963). These findings seem to justify grouping of these nuclei into a particular system of centres, probably autonomic, and characterized by an exceptional metabolic pattern.

\section{DISCUSSION}

The quantitative histochemical method described, if used under controlled conditions, permits reproducible measurements of gradients of acid phosphatase activity within a given tissue sample; these histochemical ratios were in good agreement with the ratios in biochemical measurements of homogenized brain tissue.

The distribution of acid phosphatase apparently varies very little among species as shown in histochemical studies by LANDOw et al. (1942) and by SHIMIZU (1950); this agrees with previous experience in this laboratory with human and animal material. A similar species consistency of enzyme distribution patterns was found for various oxidative enzymes (Friede, Fleming and KNoller, 1963). While both 
patterns are consistent among species, they differ markedly from each other: the pattern of acid phosphatase activity shows less variation among regions of gray matter than does that of oxidative enzymes. Thus, the respective distributions in the brain of lysosomal and mitochondrial enzymes appear to be unrelated. Most variations observed in this study appear to be related to differences in density and size of the cell population rather than to differences in energy metabolism or functional activity. One may speculate that the biological significance of acid phosphatase is more closely related to the maintenance metabolism of cells (LA VELLE, LIU and LA VeLLE, 1954) than to the energy metabolism. This concept could explain why the variation of acid phosphatase distribution is smaller than that of oxidative enzymes or capillarization (FRIEDE, 1961).

A more specific relation to protein metabolism is suggested by a striking similarity of the distribution of acid phosphatase in nerve cell perikarya and regional differences of the uptake of ${ }^{35} \mathrm{~S}$-labelled amino acids in nerve cells as documented by OEHLERT, SCHULTZE and MAURER (1958), who gave the most detailed neuroanatomical report on this subject. High rates of uptake and high levels of acid phosphatase parallel each other in the hypothalamic nuclei, in the Ammon's horn, in magnocellular nuclei throughout the brain, in the system of 'exceptional' nuclei described above, and also in the choroid plexus.

The exceptionally high activity of acid phosphatase in the supraoptic and paraventricular nuclei could conceivably be related to their neurosecretory function; one may also speculate that high activity in the choroid plexus implies a secretory function. Secretory processes do not help to explain, however, the exceptionally high activity of acid phosphatase in the pyramidal cells of the fascia dentata and in the sector $\mathrm{H} 2$ of the Ammon's horn. Both coincide with the portions most resistant to anoxic damage. Similar high resistance to anoxic damage has been shown for some of the other nuclei with high levels of acid phosphatase activity but low levels of citric acid cycle enzymes (Friede, Fleming and KNOLLER, 1963). The similarity between acid phosphatase and incorporation of thioamino acids may suggest that all of these regions are characterized by a very active protein metabolism and that acid phosphatase activity is in some way related to it.

\section{SUMMARY}

The distribution of acid phosphatase activity in the brain of the rhesus monkey was mapped by microscopic studies and quantitative measurements of histochemical preparations from fifty four regions of the brain. An average ratio of enzyme activity of 1.0 to 2.9 was recorded for white matter to gray matter. There was little variation among nuclei, less than is known for various oxidative enzymes. Cytologically, acid phosphatase activity was found in nerve cell perikarya, particularly in the large cells, and in the neuropil; the enzymic activities in perikarya and in neuropil were assumed to be in a reciprocal relationship. Exceptionally strong acid phosphatase activity was present in segment $\mathrm{H} 2$ of the Ammon's horn and in what appeared to be a specific system of autonomic centres, including the $\mathrm{N}$. supraopticus, paraventricularis, coeruleus, ectopeduncularis and others.

Acknowledgement-This investigation was supported by Public Health Service Research Grant No. NB 3250 from the National Institute of Neurological Diseases and Blindness. 


\section{REFERENCES}

Albert E. (1955) Hoppe-Seylers Z. physiol. Chem. 302, 129.

ANderson P. J. and Song S. K. (1962) J. Neuropath. exp. Neurol. 21, 263.

Cammermeyer J. (1949) J. comp. Neurol. 80, 121.

COHN P. and RichTER D. (1956) J. Neurochem. 1, 166.

ERÄNKö O. (1951) Acta physiol. scand. 24, 1.

Fleischhauer K. (1959) Nervenarzt 30, 306.

FrIEdE R. L. (1961) A Histochemical Atlas of Tissue Oxidation in the Brain Stem of the Cat. S. Karger, Basel, New York.

Friedr: R. L. and Fleming L. M. (1963) Amer. J. Anat. 113, 215.

Friede R. L., Fleming L. M. and Knoller M. (1963) J. Neurochem. 10, 263.

Gomori G. (1949) J. Lab. clin. Med. 34, 275.

Kivalo E., RinNe V. K. and MÄKELÄ S. (1958) Experientia 14, 293.

Landow H., Kabat E. and Newman W. (1942) Arch. Neurol. (Chic.) 48, 518.

la Velle A., Liu C. N. and la Velle F. W. (1954) Anat. Rec. 119, 305.

Leduc E. H., and WisLocki G. B. (1952) J. comp. Neurol. 97, 241.

Lowry O. H., Roberts N. R., Leiner K. Y., Wu M., Farr A. L. and Albers R. W. (1954) J. biol. Chem. 207, 39.

Naidoo D. and Pratt O. E. (1951) J. Neurol. Neurosurg. Psychiat. 14, 287.

Oehlert W., Schultze B, and Maurer W. (1958) Beitr. path. Anat. 119, 343.

Pearse A. G. E. (1960) Histochemistry Little, Brown and Co., Boston.

Robins E. and Smith D. E. (1953) Res. Publ. Ass. nerv. ment. Dis. 32, 305.

Robins E., SMith D. E. and Eydt K. M. (1956) J. Neurochem. 1, 77.

Samorajski T. and Fitz G. R. (1960) Lab. Invest. 9, 517.

SAMORAJSKI T. and FITZ G. R. (1961) Lab. Invest. 10, 129.

Scharrer E. and Scharrer B. (1954) Progr. Hormone Res. 10, 183.

Shimizu N. (1950) J. comp. Neurol. 93, 201.

Wislocki G. B. and Dempsey E. W. (1948) J. comp. Neurol. 88, 319. 